\title{
Erratum to: Therapeutic Approach to Patients With a Lower-Pitched Voice After Thyroidectomy
}

Inn-Chul Nam • Ja-Sung Bae • Byung-Joo Chae • Mi-Ran Shim • Yeon-Shin Hwang • Dong-Il Sun

Published online: 25 July 2013

(c) Société Internationale de Chirurgie 2013

Erratum to: World J Surg (2013) 37:1940-1950

DOI 10.1007/s00268-013-2062-1

Dong-Il Sun is the sole corresponding author of this article.

The online version of the original article can be found under doi:10. 1007/s00268-013-2062-1.

I.-C. Nam · M.-R. Shim · Y.-S. Hwang · D.-I. Sun ( $\varangle)$

Department of Otolaryngology-Head and Neck Surgery,

Seoul St. Mary's Hospital, The Catholic University of Korea,

505 Banpo-dong, Seocho-gu, Seoul 137-040, South Korea

e-mail: hnsdi@catholic.ac.kr

J.-S. Bae · B.-J. Chae

Department of Surgery, College of Medicine, The Catholic

University of Korea, Seoul, South Korea 